\title{
Toezicht op de rechtspersoon- bestuurder. De (on)mogelijkheden vanuit het perspectief van de commissaris
}

\author{
Mr.M.A.C. Appels*
}

\begin{abstract}
In de praktijk komt het voor dat een rechtspersoon fungeert als bestuurder van een andere rechtspersoon. In deze bijdrage wordt vanuit het perspectief van de commissaris stilgestaan bij de figuur van de rechtspersoon-bestuurder en wordt ingegaan op (mogelijke) knelpunten die kunnen spelen bij de taakuitoefening door de toezichthouder.
\end{abstract}

\section{Inleiding}

In de praktijk komt het voor dat een rechtspersoon fungeert als (enig) bestuurder van een andere rechtspersoon. De figuur van de rechtspersoon-bestuurder ziet men veelal in juridische structuren waarin meerdere vennootschappen met elkaar verbonden zijn, zoals in concernverhoudingen en joint ventures. In de praktijk zijn er ook voorbeelden bekend van werkmaatschappijen waarbij het bestuur wordt gevormd door een rechtspersoon-bestuurder onder toezicht van een raad van commissarissen (hierna: RvC). Het bestuur van de betreffende rechtspersoon wordt dan feitelijk gevormd door de vertegenwoordiger(s) van de betreffende rechtspersoon-bestuurder. De vraag die zich dan aandient, is door wie wordt de onderneming feitelijk bestuurd en op wie houdt de $\mathrm{RvC}$ eigenlijk toezicht? Hoe moet de $\mathrm{RvC}$ handelen bij gebrekkige transparantie en/of informatievoorziening, en welke rechtsmiddelen heeft de $\mathrm{RvC}$ in dit verband tot zijn beschikking?

De rechtspersoon-functionaris is door de wetgever nooit met open armen ontvangen. ${ }^{1} \mathrm{Zo}$ is het bij kapitaalvennootschappen onder huidig recht niet toegestaan om een rechtspersoon tot commissaris of niet-uitvoerende bestuurder te benoemen (art. 2:129a lid 1/2:140 lid 1 respectievelijk art. 2:239a lid 1/2:250 lid $1 \mathrm{BW}$ ). Ook in de literatuur zijn de nodige kanttekeningen geplaatst bij de wenselijkheid van de

Mr. M.A.C. Appels is counsel en toegevoegd notaris bij Van Doorne te Amsterdam.

1. Zie Kamerstukken II 1909/10, 217, nr. 2, p. 8, waaruit blijkt dat de minister zelfs volledig afwijzend tegenover de rechtspersoon-bestuurder stond. rechtspersoon-bestuurder. ${ }^{2}$ Door de invoering van de Wet bestuur en toezicht rechtspersonen ${ }^{3}$ zal het ook voor de vereniging en de coöperatie niet langer mogelijk zijn om een rechtspersoon te benoemen tot commissaris dan wel tot nietuitvoerende bestuurder. Dit algehele verbod komt op een moment dat er juist in de literatuur stemmen opgaan om de benoembaarheid van rechtspersonen tot commissaris of nietuitvoerende bestuurder te heroverwegen. ${ }^{4}$ Ook heeft de Raad van State in zijn advies gewezen op de ingrijpende consequenties van deze bepaling voor semipublieke instellingen, gewone stichtingen en verenigingen, aangezien bij deze entiteiten in de huidige praktijk met enige regelmaat rechtspersonen zijn benoemd tot toezichthouder. ${ }^{5}$

Wat er van deze discussie ook zij, de rechtspersoon-bestuurder is momenteel niet weg te denken uit de ondernemingsrechtpraktijk en het valt niet te verwachten dat de wetgever de benoembaarheid van de rechtspersoon als bestuurder ter discussie zal stellen. Dit gegeven noopt toezichthouders - commissarissen en niet-uitvoerende bestuurders - die zich

2. Zie ook M.L. Lennarts, The untouchables. Reactie op 'Het lichaam van de niet-uitvoerende bestuurder', MvO 2018, afl. 3-4, p. 80-85 (met naschrift K.H.M. de Roo, De inrichtingsvrijheid als uitzondering?, $\mathrm{MvO}$ 2018, afl. 3-4, p. 86-88; hierna: De Roo 2018a).

3. Zie wetsvoorstel 34491.

4. Zie voor voorstanders van de rechtspersoon als commissaris of niet-uitvoerend bestuurder: K.H.M. de Roo, De rechtspersoon als commissaris, TvOB 2015, afl. 3, p. 106; J.M. Blanco Fernández, Toezicht in het rechtspersonenrecht in het wetsvoorstel Bestuur en toezicht, in: Bestuur en toezicht bij rechtspersonen, mede in de semipublieke en non-profitsector (Preadvies van de Vereeniging 'Handelsrecht'), Zutphen: Paris 2016, p. 42; J.B.S. Hijink, Robots in de boardroom, Ondernemingsrecht 2019/3; W.J.M. van Veen, in: G. van Solinge e.a., Toezicht (VDHI nr. 151), Deventer: Wolters Kluwer 2018, p. 195 (discussieverslag); K.H.M. de Roo, Het lichaam van de niet-uitvoerend bestuurder, $\mathrm{MvO}$ 2017, afl. 10-11, p. 250-252; C.E.J.M. Hanegraaf, De rechtspersooncommissaris: een pleidooi voor het (weer) openstellen van de functie van commissaris voor rechtspersonen, TvOB 2019, afl. 3, p. 79-85. In andere zin: Lennarts 2018; E. Schmieman, Toezicht binnen de stichting, in: G. van Solinge e.a., Toezicht (VDHI nr. 151), Deventer: Wolters Kluwer 2018, p. 61-62.

5. Zie advies Afdeling advisering Raad van State en nader rapport 8 juni 2016, Kamerstukken II 2015/16, 34491, nr. 4. 


\section{Maandblad}

Ondernemingsrecht

geconfronteerd zien met een rechtspersoon-bestuurder tot actie om hun wettelijke taak naar behoren te kunnen vervullen. Op welke wijze wordt gecommuniceerd met de rechtspersoon-bestuurder, hoe valt de deskundigheid binnen het bestuur te waarborgen, en hoe houdt de $\mathrm{RvC}$ zicht op de totstandkoming van bestuursbeleid? Zomaar enkele vragen waar de wet geen duidelijk houvast biedt, maar die wel van essentieel belang zijn voor een goede corporate governance binnen de desbetreffende rechtspersoon. Indien het bestuur bestaat uit (enkel) natuurlijke personen, dan worden deze onderwerpen in de intermenselijke relatie tussen de functionarissen geadresseerd, het is voor de $\mathrm{RvC}$ immers duidelijk met wie hij van doen heeft. Indien het bestuur van de rechtspersoon bestaat uit een rechtspersoon-bestuurder, dan ligt dit echter complexer.

In deze bijdrage zal worden stilgestaan bij de vraag hoe een $\mathrm{RvC}$ van een kapitaalvennootschap zijn taak kan vervullen ingeval er een rechtspersoon tot bestuurder is benoemd, en welke problemen zich in dit verband kunnen aandienen. ${ }^{6}$ Daarbij ligt de nadruk op het dualistische stelsel, waarbij het bestuur van een rechtspersoon geheel dan wel gedeeltelijk wordt gevormd door (een) rechtspersoon-bestuurder(s). De reden voor de focus op de $\mathrm{RvC}$ is dat niet-uitvoerende bestuurders formeel niet zijn onderworpen aan een toezichtstaak die volledig gelijkstaat aan die van de RvC. In het monistische stelsel bestaat slechts een wettelijke beperking op grond waarvan de toezichthoudende taak niet door een taakverdeling kan worden ontnomen aan de niet-uitvoerende bestuurders. Niet-uitvoerende bestuurders moeten toezicht houden op hun medebestuurders, zoals iedere bestuurder toezicht moet houden op zijn medebestuurders. Dit collegiale toezicht is rechtens iets anders dan het intercollegiale toezicht dat wordt verwacht van de RvC. De praktijk leert intussen dat beide bestuursstructuren in hun uitwerking sterk op elkaar kunnen lijken. ${ }^{7}$ Veel van wat in deze bijdrage aan de orde komt, kan daarom ook relevantie hebben voor niet-uitvoerende bestuurders ingeval er rechtspersonen benoemd zijn tot uitvoerende bestuurder.

Toezicht op de rechtspersoon-bestuurder vereist een zeker inzicht in deze rechtsfiguur. Ten behoeve van dit inzicht zal ik daarom in paragraaf 2 kort stilstaan bij de positie van de rechtspersoon-bestuurder in de praktijk. Aangezien een belangrijk onderdeel van de taak van de $\mathrm{RvC}$ gericht is op het houden van toezicht op de takuitoefening van het bestuur, sta ik in paragraaf 3 stil bij de uitoefening van de bestuurstaak in het algemeen en de rol van de rechtspersoon-bestuurder daarin in het bijzonder. In paragraaf $4 \mathrm{ga}$ ik in op de toezichtstaak van de $\mathrm{RvC}$ en identificeer ik vanuit dit perspectief enke-

6. Omwille van de eenvoud laat ik het verenigingen- en stichtingenrecht onbesproken. Daarmee sluit ik niet uit dat mijn uiteenzetting ook voor andere rechtspersoonsvormen dan de naamloze vennootschap en de besloten vennootschap van belang kan zijn.

7. Zie o.a. S.R. Schuit, The chairman makes or breaks the board. De rol van de chairman van Nederlandse beursgenoteerde ondernemingen, Amsterdam: Gopher 2010. le knelpunten die zich kunnen voordoen indien het bestuur wordt gevormd door een rechtspersoon-bestuurder. In paragraaf 5 geef ik enkele aanbevelingen voor een adequaat toezicht op de rechtspersoon-bestuurder en in paragraaf 6 ga ik in op de vraag welke (rechts)middelen de $\mathrm{RvC}$ in dit verband tot zijn beschikking heeft.

\section{Toelaatbaarheid en praktisch nut}

De huidige wet kent geen bepaling die de benoeming van een rechtspersoon als bestuurder van een andere rechtspersoon verbiedt. Indachtig het uitgangspunt dat iedere rechtspersoon de vrijheid toekomt om zijn eigen inrichting te bepalen, behoudens voor zover de wet deze vrijheid beperkt, volgt hieruit dat de rechtspersoon-bestuurder in beginsel is toegestaan. ${ }^{8}$ Dit gegeven wordt bevestigd door artikel 2:11 BW, waarin wordt gesproken van 'een rechtspersoon als bestuurder van een andere rechtspersoon' en dus de bestaanbaarheid van de rechtspersoon-bestuurder onderkend wordt. Tevens wordt voor de toepassing van de evenwichtige man-vrouwverdeling als bedoeld in artikel 2:166/276 BW expliciet rekening gehouden met de situatie dat een rechtspersoon-bestuurder zitting kan hebben in een bestuur. Voor de verdere toepassing van Boek 2 BW wordt geen onderscheid gemaakt tussen de natuurlijke persoon-bestuurder en de rechtspersoonbestuurder. Boek 2 BW laat vennootschappen dus de ruimte om, indien gewenst, een rechtspersoon tot bestuurder te benoemen. Buiten Boek 2 BW wordt het bestaan van de rechtspersoon-bestuurder in artikel 106a lid 2 Fw bevestigd, waarin is bepaald dat een bestuursverbod mede kan worden uitgesproken jegens de bestuurder van een of meer rechtspersoon-bestuurders.

Zoals in de inleiding reeds opgemerkt, heeft de praktijk in de rechtspersoon-bestuurder een handzaam en praktisch instrument gevonden, met name in concernverhoudingen en joint ventures. Als voorbeeld noem ik een onderneming bestaande uit een holding die - direct dan wel indirect - meerdere dochtervennootschappen, waaronder dochtervennootschap A en dochtervennootschap B, houdt en deze centraal aanstuurt. Deze dochtervennootschappen dienen allemaal te worden bestuurd. Stel dat een natuurlijke persoon bestuurder is van zowel de holding als deze dochtervennootschappen en dat deze functionaris besluit zijn of haar carrière elders voort te zetten, dan betekent dit dat voor elke vennootschap afzonderlijke ontslag- en benoemingsbesluiten genomen moeten worden. Indien bij deze dochtervennootschappen holding was benoemd tot bestuurder, dan zou een bestuurswissel op het niveau van holding volstaan hebben. Binnen het bestuur van de rechtspersoon-bestuurder (holding) kan tevens door middel van taakverdeling en delegatie worden bepaald dat één bestuurder meer in het bijzonder belast zal zijn met het namens holding uitvoering geven aan de bestuurstaak bij dochtervennootschap A, terwijl een medebestuurder de taak toebedeeld krijgt om uitvoering te geven aan de bestuurstaak

8. HR 9 juli 2010, ECLI:NL:HR:2010:BM0976, NJ 2010/544 m.nt. P. van Schilfgaarde (ASMI), r.o. 4.4.2. Zie ook De Roo 2018a, p. 86. 
van holding bij dochtervennootschap B. Om dit te bereiken zijn bestuurswissels niet nodig. Ook aanbieders van trustdiensten als bedoeld in de Wet toezicht trustkantoren 2018 maken gebruik van de rechtspersoon-bestuurder. Deze trustkantoren treden regelmatig op als (mede)bestuurder van in Nederland gevestigde vennootschappen die onderdeel uitmaken van internationale structuren. Door het benoemen van een speciaal voor dit doeleinde opgerichte rechtspersoon-bestuurder wordt continuïteit binnen het bestuur gewaarborgd en voorkomen dat cliënten geconfronteerd worden met in- en uittredende bestuurders ten gevolge van personele wisselingen binnen het betreffende trustkantoor.

Naast deze historisch gegroeide praktijk kan ten slotte nog worden gewezen op functies die rechtspersoon-bestuurders in de toekomst wellicht kunnen vervullen, zoals in het bijzonder de door Möslein en Hijink gesignaleerde mogelijkheden van kunstmatige intelligentie op dit punt. ${ }^{9}$ Deze vergezichten laat ik verder voor wat zij zijn. Het is niettemin belangrijk te zien dat het denken over het praktisch nut van de rechtspersoonbestuurder niet stilstaat, maar zich blijft ontwikkelen. De gebruiksmogelijkheden van de rechtspersoon-bestuurder lijken daarom eerder toe dan af te nemen. Het is om deze reden eens te meer van belang dat ook het toezicht op de rechtspersoon-bestuurder goed doordacht wordt.

\section{Functioneren van de rechtspersoon-bestuurder}

Voor een $\mathrm{RvC}$ kan de rechtspersoon-bestuurder iets ongrijpbaars hebben. In de praktijk blijkt dat commissarissen - met name de grote groep commissarissen die gewend is toezicht te houden op natuurlijke personen - zich voor verschillende moeilijkheden geplaatst zien indien toezicht gehouden dient te worden op een rechtspersoon-bestuurder. De vraag rijst al snel hoe het toezicht op de rechtspersoon-bestuurder praktisch moet worden vormgegeven, en hoe moet worden omgegaan met de verschillende personen die zowel voor de schermen (aan de bestuurstafel) als achter de schermen (buiten de bestuurstafel) bij de bestuurlijke taakuitoefening betrokken zijn. Op welke wijze communiceert de $\mathrm{RvC}$ bijvoorbeeld met de rechtspersoon-bestuurder, en hoe kan de $\mathrm{RvC}$ deskundigheid binnen het bestuur waarborgen als op voorhand niet duidelijk is welke natuurlijke personen de rechtspersoon-bestuurder ter zake vertegenwoordigen? Om bovenstaande vraagstukken te kunnen adresseren is inzicht in de taakvervulling door de rechtspersoon-bestuurder van groot belang.

\subsection{Vertegenwoordiging}

Indien het bestuur wordt gevormd door een of meer natuurlijke personen, dan is het voor commissarissen duidelijk

9. F. Möslein, Robots in the boardroom: artificial intelligence and corporate law, in: W. Barfield \& U. Pagallo (red.), Research handbook on the law of artificial intelligence, Cheltenham: Edward Elgar 2018, p. 649 e.v.; Hijink 2019. Kritisch over de robotbestuurder: S.W. van de Ven, De veranderende taak van bestuurders in het tijdperk van AI, MvO 2020, afl. 7 , p. 193-201. met wie zij van doen hebben. Bij een bestuur gevormd door een rechtspersoon ligt dit anders. De rechtspersoonbestuurder zal bij het vervullen van zijn bestuurstaak worden vertegenwoordigd door degene(n) die daartoe op grond van de wet, de statuten of een volmacht bevoegd is (zijn). Vanwege de verschillende denkbare personen die de rechtspersoonbestuurder bij zijn taakvervulling kunnen vertegenwoordigen, kan het voorkomen dat verschillende personen de rechtspersoon-bestuurder ten aanzien van verschillende bestuursaangelegenheden vertegenwoordigen. Zo kan zich de situatie voordoen dat de $\mathrm{RvC}$ in de onderlinge communicatie met het bestuur gedurende het jaar contact heeft met persoon $\mathrm{A}$, terwijl tijdens een belangrijke vergadering persoon $\mathrm{B}$ aanwezig is. Ook is het mogelijk dat de rechtspersoon-bestuurder door meerdere personen gezamenlijk vertegenwoordigd wordt of dat gedurende een bepaalde periode de ene persoon namens de rechtspersoon-bestuurder handelt, om daarna te worden afgewisseld door een andere persoon die tot dan toe voor de $\mathrm{RvC}$ onbekend was.

De mogelijkheden tot vertegenwoordiging van de rechtspersoon-bestuurder in zijn taakuitoefening zijn niet onbegrensd. Het is duidelijk dat de personen die op grond van de wet of de statuten bevoegd zijn de rechtspersoon-bestuurder te vertegenwoordigen namens deze in het bestuur kunnen plaatsnemen, alsook dat - met name waar het gaat om de vertegenwoordiging op statutaire grondslag - de inrichting van de rechtspersoon-bestuurder ruimte kan maken voor een veelheid aan vertegenwoordigingsbevoegde personen. Met betrekking tot de vertegenwoordiging op basis van volmacht kan hierover anders worden gedacht. Het staat ter discussie of een bestuurdersvolmacht mag worden verleend aan anderen dan medebestuurders. ${ }^{10}$ Ik ben van mening dat bestuurders op grond van hun persoonlijke capaciteiten in functie worden benoemd door het daartoe bevoegde orgaan. Om deze reden acht ik het niet mogelijk dat bestuurders aan andere (rechts)personen dan bestuurders een bestuursvolmacht verlenen. Wat van deze kwestie verder ook zij, duidelijk is dat de rechtspersoon-bestuurder door een diverse groep personen vertegenwoordigd kan worden, waarbij het voor de $\mathrm{RvC}$ op voorhand niet altijd even duidelijk zal zijn wie deze personen zijn.

\subsection{Richtsnoer}

Een laatste aspect van de rechtspersoon-bestuurder dat van belang is voor een goed begrip van zijn functioneren is het richtsnoer bij de taakuitoefening. Zoals iedere bestuurder moet de rechtspersoon-bestuurder zich richten naar het belang van de vennootschap die hij bestuurt (art. 2:129/239 lid 5 BW). Daarbij mag de rechtspersoon-bestuurder de belan-

10. Vgl. K.A.M. van Vught, De aandeelhouder of bestuurder krachtens levenstestament - new kid on the block of verdoolde?, WPNR 2018, afl. 7210, p. 749-750; P.M.J.H. ten Broecke, De vertegenwoordiger van bestuurders en commissarissen van de BV en het persoonlijk karakter van hun functie. Naar een nieuw criterium?, WPNR 2019, afl. 7248, p. 547-553. 


\section{Maandblad}

Ondernemingsrecht

gen van betrokken derden niet onnodig of onevenredig schaden. ${ }^{11}$ Een interessante vraag is of de bestuurder of bestuurders van de rechtspersoon-bestuurder bij de vervulling van de op hen rustende bestuurstaak binnen de rechtspersoonbestuurder altijd in het belang van de rechtspersoonbestuurder dienen te handelen. Stel bijvoorbeeld dat een vennootschap zowel aandeelhouder als rechtspersoonbestuurder van een andere vennootschap is: het is geen vanzelfsprekendheid dat de belangen van de rechtspersoonbestuurder (als bestuurder, aandeelhouder of anderszins) altijd parallel lopen aan het belang van de vennootschap waarin hij een bestuurdersfunctie vervult. Moeten de bestuurders van de rechtspersoon-bestuurder in dat geval het belang van de rechtspersoon-bestuurder laten voorgaan op dat van de bestuurde rechtspersoon? Of wellicht het omgekeerde?

Het antwoord op deze vraag is volgens mij voor naar Nederlands recht opgerichte rechtspersoon-bestuurders als volgt. Op de rechtspersoon-bestuurder rust op grond van artikel 2:129/239 lid 5 BW de plicht om zich te richten naar het belang van de rechtspersoon waarvan hij bestuurder is. Het gaat hierbij om een rechtsplicht waaraan de rechtspersoonbestuurder zich heeft te houden. Het bestuur van de rechtspersoon-bestuurder is op zijn beurt verplicht om zich naar het belang van de rechtspersoon-bestuurder te richten. Naast deze plicht om in het belang van de rechtspersoon te handelen geldt echter eveneens een plicht om het rechtsconforme handelen van de rechtspersoon-bestuurder te waarborgen. Op het bestuur van de rechtspersoon-bestuurder rust een nalevingsplicht. ${ }^{12}$ Deze nalevingsplicht brengt met zich dat dit bestuur moet waarborgen dat de rechtspersoon-bestuurder zijn eigen plichten naleeft, daaronder begrepen de plicht te handelen in het belang van de bestuurde rechtspersoon. Dit betekent dat het bestuur van de rechtspersoon-bestuurder niet enkel het belang van laatstgenoemde, maar indirect ook het belang van de door deze bestuurde rechtspersoon moet behartigen. Gesteld zou daarom kunnen worden dat het vennootschappelijk belang van de door de rechtspersoon-bestuurder bestuurde vennootschap doorwerkt in de taak van het bestuur van de rechtspersoon-bestuurder.

\subsection{Aansprakelijkheid}

Hoewel het uiteraard belangrijk is te bezien wat de taak is van de rechtspersoon-bestuurder, mag niet worden vergeten dat het de aansprakelijkheidsdreiging expost bij een onbehoorlijke taakvervulling is die een behoorlijke takkervulling dient te waarborgen. Hoezeer personen zich daadwerkelijk laten leiden door de dreiging van aansprakelijkheid doet voor nu niet ter zake, maar dat een aansprakelijkheidsdreiging een middel is om een persoon tot handelen te bewegen, zal wel niemand

11. HR 4 april 2014, ECLI:NL:HR:2014:799, JOR 2014/290 m.nt. R.G.J. de Haan (Cancun), r.o. 4.2.2.

12. K.H.M. de Roo, De nalevingsplicht van het bestuur van rechtspersonen, Ondernemingsrecht 2018, afl. 1, p. 3-12. ontkennen. ${ }^{13}$ Het is om deze reden voor de $\mathrm{RvC}$ van belang te weten wie aansprakelijk kan zijn voor onbehoorlijke taakvervulling door de rechtspersoon-bestuurder. In de eerste plaats is dit vanzelfsprekend de rechtspersoon-bestuurder zelf. ${ }^{14} \mathrm{Om}$ echter te voorkomen dat de beperkte aansprakelijkheid van de rechtspersoon misbruikt wordt om bestuurdersaansprakelijkheid te ontgaan, bepaalt het hiervoor al aangehaalde artikel 2:11 BW dat de aansprakelijkheid van een rechtspersoonbestuurder tevens hoofdelijk rust op ieder die ten tijde van het ontstaan van de aansprakelijkheid van de rechtspersoonbestuurder daarvan bestuurder is. De strekking van deze regeling is dat de natuurlijke personen die feitelijk achter de rechtspersoon-bestuurder schuilgaan, aangesproken kunnen worden in geval van aansprakelijkheid van de rechtspersoonbestuurder. Deze doorbraak van aansprakelijkheid werkt zowel in relatie tot interne bestuurdersaansprakelijkheid (art. 2:9 BW) als in relatie tot externe bestuurdersaansprakelijkheid (art. 6:162 BW). ${ }^{15}$ Dit betekent dat bij een gebrekkig functioneren van de rechtspersoon-bestuurder het in beginsel ook de bestuurders van de rechtspersoon-bestuurder zijn die het risico van aansprakelijkheid dragen. Dit maakt de bestuurders van de rechtspersoon-bestuurder voor de $\mathrm{RvC}$ belangrijke personen, nu zij uiteindelijk 'skin in the game' hebben ter zake van de behoorlijke taakvervulling van de rechtspersoon-bestuurder. ${ }^{16}$

\section{Toezicht en aandachtspunten}

$\mathrm{Na}$ een verkenning van de rechtspersoon-bestuurder en de wijze waarop zijn taakvervulling genormeerd is en in de praktijk kan functioneren, kan worden geanalyseerd wat de rol van de $\mathrm{RvC}$ is ten opzichte van de rechtspersoon-bestuurder en hoe hij aan deze rol in de praktijk invulling zou kunnen geven. De RvC heeft als bekend tot wettelijke taak het houden van toezicht op het beleid van het bestuur en op de algemene zaken in de vennootschap. Daarnaast staat de RvC het bestuur met raad terzijde (art. 2:140/250 lid 2 BW). De takuitoefening van de $\mathrm{RvC}$ is de afgelopen decennia, mede onder invloed van de voor beursvennootschappen opgestelde Corporate Governance Code, significant geëvolueerd. Meer dan in het verleden heerst een taakopvatting die de commissaris een proactieve rol in de governance van vennootschappen toeschrijft. Zo wordt de commissaris tegenwoordig geacht vaak intensief betrokken te zijn bij het aansturen van de onderneming, de ontwikkeling van een daarop toegesneden strategie

13. Zie over aansprakelijkheid als strategie voor het reguleren van bestuurdershandelen J. Armour e.a., The basic governance structure: The interests of shareholders as a class, in: R. Kraakman e.a., The anatomy of corporate law, Oxford: Oxford University Press 2017, p. 69-71.

14. Zie HR 8 december 2006, ECLI:NL:HR:2006:AZ0758, NJ 2006/659; JOR 2007/38 (Ontvanger/Roelofsen), waar is bepaald dat voor aansprakelijkheid de drempel van ernstige verwijtbaarheid geldt.

15. HR 17 februari 2017, ECLI:NL:HR:2017:275, NJ 2017/215 m.nt. P. van Schilfgaarde (Le Roux), r.o. 3.4.3.

16. Zie voor het belang van deze gedachte in breder verband N.N. Taleb, Skin in the game, New York: Random House 2018. 
en het vaststellen en bewaken van een beleid op het gebied van risicobeheersing. ${ }^{17}$

De intensiteit van het door de $\mathrm{RvC}$ uit te oefenen toezicht hangt vanzelfsprekend nauw samen met het vaarwater waarin de vennootschap zich begeeft. Indien er binnen de onderneming niets aan de hand is, dan zal de $\mathrm{RvC}$ zich betrekkelijk lijdelijk kunnen opstellen bij de uitoefening van zijn taken. Indien deze fase van relatieve rust echter wordt verlaten door incidenten of economische ontwikkelingen als gevolg waarvan de onderneming onder druk komt te staan, zal de $\mathrm{RvC}$ moeten opschalen. De $\mathrm{RvC}$ zal zich in deze fase intensief moeten bemoeien met de onderneming, en zich binnen de organisatie en desgewenst door deskundigen moeten laten informeren. Mocht deze fase zich onverhoopt ontwikkelen tot een crisis waardoor de continuiteit van de onderneming in gevaar is, dan zal de $\mathrm{RvC}$ maatregelen moeten treffen in een poging het tij te keren. $^{18}$

De hierboven genoemde wisselingen in de intensiteit van het toezicht en de relatie daarvan met de verschillende fasen waarin de onderneming zich kan begeven, zijn relevant voor de verhouding tussen de $\mathrm{RvC}$ en de rechtspersoon-bestuurder. Met name waar de $\mathrm{RvC}$ zich daadwerkelijk proactief moet opstellen, moet helderheid bestaan over hoe de commissarissen zich tot de rechtspersoon-bestuurder verhouden. Hoe wordt bijvoorbeeld gecommuniceerd tussen de $\mathrm{RvC}$ en de rechtspersoon-bestuurder, op welke wijze verkrijgt (of haalt) de $\mathrm{RvC}$ de nodige informatie van de rechtspersoon-bestuurder wanneer deze uitblijft, en op welke wijze kan waar nodig worden bijgestuurd? Enkele aandachtspunten kunnen in dit verband worden uitgelicht.

\subsection{Identificatie en communicatie}

Iedere op zijn taak berekende commissaris zal kunnen beamen dat een eerste aandachtspunt bij een goede vervulling van een commissariaat het zorgen voor een vlot verlopende communicatie met het bestuur is. Goede communicatie tussen bestuur en $\mathrm{RvC}$ is essentieel voor een goed functionerende governance; of het nu gaat om informatie-uitwisseling of het uitvoering geven aan de adviserende rol van de RvC. Dit geldt in versterkte mate wanneer er sprake is van een rechtspersoonbestuurder. Het zal namelijk niet altijd duidelijk zijn voor een $\mathrm{RvC}$ wie de rechtspersoon-bestuurder rechtens vertegenwoordigt en hiermee het eerste aanspreekpunt voor de $\mathrm{RvC}$ is.

Het ligt voor de hand dat de vennootschap deze informatie uit eigen beweging aan de $\mathrm{RvC}$ verstrekt en de $\mathrm{RvC}$ informeert indien deze informatie niet meer accuraat is. Mocht de $\mathrm{RvC}$ beschikken over aanwijzingen dat de informatie niet juist of

17. Zie ook S.R. Schuit \& C. Jaspers, De gewijzigde taakopvattingen van commissarissen en hun voorzitter, Ondernemingsrecht 2017/71.

18. Zie ook T. Salemink \& M.P. Nieuwe Weme, Toezicht op de jaarrekening door de raad van commissarissen, in: J.B.S. Hijink e.a. (red.), Handboek jaarrekeningenrecht 2020 (VDHI nr. 164), Deventer: Wolters Kluwer 2020, p. 277-320. onvolledig is, dan heeft de $\mathrm{RvC}$ de taak om zelfstandig onderzoek te doen. Indien de rechtspersoon-bestuurder een Nederlandse rechtspersoon betreft, dan kan de $\mathrm{RvC}$ het handelsregister van de Kamer van Koophandel raadplegen om na te gaan wie (uiteindelijk) de rechtspersoon-bestuurder vertegenwoordigt. Dit betekent echter niet per definitie dat de $\mathrm{RvC}$ voldoende heeft aan deze informatie. Het is goed denkbaar dat een rechtspersoon-bestuurder een meerhoofdig bestuur kent en dat bij delegatie de bevoegdheid om de betreffende rechtspersoon te vertegenwoordigen is toebedeeld aan één persoon. Deze informatie is niet per definitie kenbaar uit publieke bronnen.

De identificatie wordt nog lastiger dan wel onmogelijk indien een buitenlandse rechtspersoon wordt benoemd tot rechtspersoon-bestuurder van een Nederlandse rechtspersoon. Hoe kan de $\mathrm{RvC}$ zijn wettelijke taak behoorlijk uitoefenen indien niet valt na te gaan wie de bestuurder-rechtspersoon vertegenwoordigt en het daardoor niet duidelijk is met wie de $\mathrm{RvC}$ moet communiceren, en wie bevoegd is om namens de rechtspersoon-bestuurder vergaderingen bij de wonen? In het belang van goede communicatie en informatie-uitwisseling dient het te allen tijde volstrekt duidelijk te zijn welke natuurlijke persoon de rechtspersoon-bestuurder (uiteindelijk) vertegenwoordigt.

\subsection{Behoorlijke organisatie van rechtspersoon- bestuurder}

Voor een behoorlijke taakvervulling door het bestuur is vereist dat een bestuurder handelt zoals van een redelijk bekwaam bestuurder in de gegeven omstandigheden verwacht mag worden. Indien het bestuur van een vennootschap wordt gevormd door een rechtspersoon-bestuurder, dan valt of staat het goed functioneren van deze rechtspersoon-bestuurder met de geschiktheid en deskundigheid van de personen die de rechtspersoon-bestuurder ter zake vertegenwoordigen en van de personen die anderszins bij deze taakvervulling - bijvoorbeeld in een ondersteunende functie - betrokken zijn. De RvC dient te waarborgen dat de rechtspersoon-bestuurder te allen tijde voldoet aan de objectieve 'maatman-bestuurder'-norm en zal er daarom op moeten toezien dat de rechtspersoonbestuurder behoorlijk is georganiseerd en zich voor zijn taakuitoefening bedient van de juiste geschikte mensen. ${ }^{19}$ Deze persoonlijke bezetting van de rechtspersoon-bestuurder werkt in zekere zin ook door in het eerdergenoemde aandachtspunt van identificatie en communicatie. Zo kan worden betwijfeld of een $\mathrm{RvC}$ zijn taak behoorlijk kan vervullen indien niet duidelijk is wie de rechtspersoon-bestuurder primair vertegenwoordigt dan wel wie feitelijk het beleid bepaalt, en tot wie de commissarissen zich dan moeten richten. De RvC heeft ook tot taak het houden van toezicht op het functioneren van het bestuur. Hierbij is de bezetting van de rechtspersoon-

19. Zie voor de maatman-bestuurder ook L. Timmerman, Beginselen van bestuurdersaansprakelijkheid, in: J.B. Huizink e.a., Bestuurdersaansprakelijkheid op grond van art. 2:9 BW en art. 6:162 BW (ZIFO-reeks, deel 22), Deventer: Wolters Kluwer 2017, p. 14. 


\section{Maandblad \\ Ondernemingsrecht}

bestuurder van belang. Een parallel kan worden getrokken met het oordeel van de Ondernemingskamer in Meavita. In deze uitspraak overwoog de Ondernemingskamer dat de combinatie van het ontbreken van profielschetsen en functioneringsen beoordelingsgesprekken, of enige andere objectieve reflectie op de inhoud van de taken en de takkvervulling van het bestuur, een nalatigheid en een ernstig tekortschieten van de $\mathrm{RvC}_{\text {vormde. }}{ }^{20}$ Een vergelijkbare verplichting voor de $\mathrm{RvC}$ laat zich formuleren met betrekking tot de geschiktheid en de beoordeling van het functioneren van de personen die ten behoeve van de rechtspersoon-bestuurder handelen.

\subsection{Beleidsvrijheid rechtspersoon-bestuurder}

Het staat tot bestuurder benoemde natuurlijke personen in principe vrij om binnen de grenzen van het recht naar eigen inzicht te besturen. Moreel kunnen zij misschien bepaalde beleidslijnen persoonlijk afwijzen, maar rechtens kunnen zij hun bevoegdheden - mits rechtmatig - gebruiken naar eigen voorkeur. Voor de rechtspersoon-bestuurder kan dit echter anders zijn. Het handelen van de rechtspersoon-bestuurder wordt mede bepaald door zijn interne bevoegdheidsverdeling. Zo kan statutair worden bepaald dat een bestuursbesluit van de rechtspersoon-bestuurder dat betrekking heeft op het handelen als bestuurder bij een andere vennootschap voorafgaande goedkeuring behoeft van een ander orgaan van de rechtspersoon-bestuurder. Tevens is het mogelijk dat de statuten van de rechtspersoon-bestuurder met de rechtsvorm van een besloten vennootschap bepalen dat het bestuur zich dient te gedragen naar de (concrete) aanwijzingen van een ander orgaan. ${ }^{21}$ Het bestuur is alsdan gehouden de aanwijzingen op te volgen, tenzij er een grond bestaat voor weigering daarvan, zoals bij de besloten vennootschap strijd met het belang van de vennootschap (art. 2:239 lid 4 BW).

Voor de $\mathrm{RvC}$ is het essentieel om te weten of de vertegenwoordiger(s) van de rechtspersoon-bestuurder intern volledige beleidsvrijheid toekomt. Stel bijvoorbeeld dat de statuten en/ of reglementen van de rechtspersoon-bestuurder specifieke regelingen bevatten betreffende de uitoefening van de bestuurstaak bij andere vennootschappen. In dat geval dienen de bestuurders van de rechtspersoon-bestuurder in hun interne verhouding tot de rechtspersoon-bestuurder te handelen conform deze regeling en treft hen een ernstig verwijt van onbehoorlijke takkvervulling indien zij deze verplichting schenden. ${ }^{22}$ Dit betekent concreet dat de personen die handelen namens de rechtspersoon-bestuurder geen volledige autonomie toekomt bij de vervulling van hun taak namens de rechtspersoon-bestuurder. Een $\mathrm{RvC}$ zal op de hoogte moeten zijn of, en zo ja, in welke mate de personen die de rechts-

20. Hof Amsterdam (OK) 11 november 2015, ECLI:NL:GHAMS: 2015:4454, JOR 2016/61 m.nt. P. van Schilfgaarde (Meavita), r.o. 13.3.

21. Voor de naamloze vennootschap geldt op grond van art. 2:129 lid 4 BW dat slechts instructies gegeven kunnen worden die de algemene lijnen van het te voeren beleid op nader in de statuten aangegeven terreinen betreffen.

22. HR 29 november 2002, ECLI:NL:HR:2002:AE7011 (Berghuizer Papierfabriek). persoon-bestuurder vertegenwoordigen de vrijheid toekomt om naar eigen inzicht te handelen als het gaat om de uitoefening van de bestuurdersfunctie door de rechtspersoonbestuurder. Ook kan het op de weg van de $\mathrm{RvC}$ liggen om de rechtspersoon-bestuurder te schorsen (indien deze bevoegdheid niet statutair is beperkt of uitgesloten als bedoeld in art. 2:147/257 BW), indien blijkt dat binnen de rechtspersoon-bestuurder ongewenste wijzigingen van de governance hebben plaatsgevonden, zoals bijvoorbeeld het onderwerpen van alle bestuursbesluiten die zien op de uitoefening van de bestuurstaak door de rechtspersoon-bestuurder als gevolg waarvan de vertegenwoordigers van de rechtspersoonbestuurder feitelijk niet meer kunnen besturen.

\subsection{Buitenlandse rechtspersoon-bestuurder}

De buitenlandse rechtspersoon-bestuurder is al eerder in deze bijdrage aangehaald. Naar Nederlands recht is het mogelijk om zowel Nederlandse als buitenlandse rechtspersonen te benoemen tot bestuurder. Indien een buitenlandse rechtspersoon wordt benoemd tot bestuurder van een vennootschap dienen zich additionele (governance)vraagstukken aan. De personen die de buitenlandse rechtspersoon-bestuurder besturen, zijn immers onderworpen aan een ander rechtsstelsel dan Nederlands recht (art. 10:118 jo. art. 10:119 BW). Eerder merkte ik al op dat de objectieve identificatie van de vertegenwoordiger(s) van de rechtspersoon-bestuurder in de praktijk moeilijk, zo niet onmogelijk is, met alle gevolgen van dien voor de onderlinge communicatie. Indien een buitenlandse rechtspersoon tot bestuurder is benoemd, zal de $\mathrm{RvC}$ op dit punt geconfronteerd worden met een (waarschijnlijk) onbekend vertegenwoordigingsregime. Een buitenlandse rechtspersoonbestuurder noopt dus tot alertheid.

Verder merk ik op dat het richtsnoer voor de uitoefening van de bestuurstaak onder het op de rechtspersoon-bestuurder toepasselijk recht een ander kan zijn dan het geval is in Nederland. Ik noem ter illustratie het streven naar (al dan niet) maximale aandeelhouderswaarde zoals geldt in verschillende Angelsaksische rechtsstelsels. Het valt ten zeerste te betwijfelen of de eerder in paragraaf 3.2 opgebrachte stelling dat het vennootschappelijk belang van de door de rechtspersoonbestuurder bestuurde vennootschap doorwerkt in de taak van het bestuur van de rechtspersoon-bestuurder, ook in dergelijke gevallen standhoudt. De $\mathrm{RvC}$ doet er goed aan zich ervan te vergewissen of het feit dat de rechtspersoon-bestuurder is onderworpen aan een ander rechtsstelsel, invloed heeft op de feitelijke taakuitoefening van de rechtspersoon-bestuurder en het besluitvormingsproces.

Een verder complicerende factor in dit verband is dat artikel 2:11 BW, waarin de regeling voor doorbraak van bestuurdersaansprakelijkheid is opgenomen, niet doorwerkt in het incorporatierecht dat toepasselijk is op de buitenlandse rechts- 
persoon-bestuurder. ${ }^{23}$ Als gevolg hiervan bestaat er mogelijk geen deugdelijk mechanisme waarmee natuurlijke personen gesanctioneerd kunnen worden indien vast komt te staan dat de rechtspersoon-bestuurder ernstig verwijtbaar heeft gehandeld. Indien de rechtspersoon-bestuurder aansprakelijk wordt gehouden voor (persoonlijk) ernstig verwijtbaar handelen, dan is de vraag of de uiteindelijke bestuurders van de rechtspersoon-bestuurder eveneens een aansprakelijkheidsrisico lopen. De RvC dient erop bedacht te zijn dat een verminderd aansprakelijkheidsrisico van deze bestuurders kan noodzaken tot een verscherpt toezicht.

\section{Nadere invulling om toezicht te waarborgen?}

Bovenstaande gesignaleerde problemen leiden naar mijn mening niet tot de conclusie dat een $\mathrm{RvC}$ geen prudent toezicht kan houden op een bestuur waarin een of meer rechtspersonen tot bestuurder benoemd zijn. Wel ben ik van mening dat indien voor deze bestuursstructuur wordt gekozen, het voor de praktijk wenselijk is dat nadere statutaire en reglementaire bepalingen worden opgenomen ter waarborging van voldoende checks and balances in de verhouding tussen bestuur en $\mathrm{RvC}$.

\subsection{Vaste vertegenwoordiger}

Het lijkt vreemd dat in een tijd waarin transparantie hoog in het vaandel staat en zelfs de uiteindelijk belanghebbende of belanghebbenden van een rechtspersoon (UBO) met naam en toenaam in het handelsregister van de Kamer van Koophandel dienen te worden geregistreerd, uit datzelfde handelsregister niet altijd valt op te maken wie een rechtspersoon-bestuur vertegenwoordigt en daarmee feitelijk de betreffende rechtspersoon bestuurt. ${ }^{24}$ Aan dit bezwaar kan voor een belangrijk deel tegemoet worden gekomen door het (wettelijk of statutair) voorschrijven van een vaste vertegenwoordiger van de rechtspersoon-bestuurder. Een vaste vertegenwoordiger biedt de $\mathrm{RvC}$ vrijwel dezelfde houvast als een tot bestuurder benoemde natuurlijke persoon, met dien verstande dat de kwesties die spelen rond de interne organisatie van de rechtspersoon-bestuurder - zoals goedkeuringsrechten en instructierechten van andere organen dan het bestuur van de rechtspersoon-bestuurder - hiermee niet verdwenen zijn. Over de (on)wenselijkheid van een aanwijs- en registratieplicht van een vaste vertegenwoordiger is in de literatuur reeds gepubliceerd, waarbij deze problematiek voornamelijk vanuit aansprakelijkheidsperspectief is geschreven. ${ }^{25}$

Hoewel ik de noodzakelijkheid van een wettelijke verplichting tot registratie van een vaste vertegenwoordiger niet in alle gevallen zie, valt er vanuit een governanceperspectief veel voor te zeggen om in ieder geval in interne verhoudingen volledige

23. Zie ook J.B. Huizink, De rechtspersoon-bestuurder en art. 2:11 BW, O\&F 2018, afl. 2, p. 5-10 en C.E.J.M. Hanegraaf, Artikel 2:11 BW: 'doorgeefluik van aansprakelijkheid' of 'aansprakelijkheidsvergroter'?, MvO 2017, afl. 8-9, p. 184-189.

24. Zie ook Lennarts 2018

25. Zie ook A.G. Wennekes \& J.A. Troost, De vaste vertegenwoordiger van een rechtspersoon, TvOB 2015, afl. 4, p. 137-144 transparantie te waarborgen indien een rechtspersoon wordt benoemd tot bestuurder. $\mathrm{Nu}$ de Minister van Veiligheid en Justitie in een eerder stadium bezwaren heeft geuit tegen de introductie van de vaste vertegenwoordiger ${ }^{26}$ valt wetgeving op dit vlak op korte termijn niet te verwachten. Bij gebrek aan wettelijke regeling is een $\mathrm{RvC}$ aangewezen op het thans geldende wettelijke instrumentarium waartoe de $\mathrm{RvC}$ beschikt om een regeling te treffen op grond waarvan de rechtspersoonbestuurder voorafgaand aan zijn taakuitoefening een of meer personen aanwijst die belast zullen zijn met het namens de rechtspersoon-bestuurder uitoefenen van de bestuurdersfunctie. Hiermee wordt bereikt dat de $\mathrm{RvC}$ een vast aanspreekpunt heeft waarop hij zich bij zijn takuitoefening primair kan richten. Dit is in zeker opzicht in lijn met onder meer het Belgische systeem, waarin op grond van de wet naast een rechtspersoon-bestuurder altijd een natuurlijke persoon als 'zaakvoerder' (dit is een vaste vertegenwoordiger) dient te worden aangewezen.

Op grond van deze regeling dient de $\mathrm{RvC}$ te allen tijde op de hoogte te zijn van de omvang van de vertegenwoordigingsbevoegdheid en van de verhouding van de vaste vertegenwoordiger ten opzichte van andere personen binnen de rechtspersoon-bestuurder, zoals een orgaan dat de vaste vertegenwoordiger kan instrueren. Ook dient de $\mathrm{RvC}$ van iedere aanwijzing dan wel een wijziging van een aanwijzing van een vaste vertegenwoordiger op de hoogte te worden gebracht en zal hij navraag moeten doen indien deze informatieverschaffing uitblijft. Op deze manier kan ervoor worden gezorgd dat de $\mathrm{RvC}$ weet wie feitelijk bestuurt, waardoor efficiënt kan worden gecommuniceerd indien de $\mathrm{RvC}$ informatie van het bestuur verlangt, het bestuur wil adviseren of andere bevoegdheden wil uitoefenen.

\subsection{Samenstelling en deskundigheid}

Naast het aanwijzen van een vaste vertegenwoordiger verdienen de samenstelling van het bestuur van de rechtspersoonbestuurder en de deskundigheid van de personen die bij zijn taakuitoefening betrokken zijn bijzondere aandacht. Dat een adequate samenstelling van een orgaan van evident belang is voor het goed functioneren van de rechtspersoon werd recentelijk nog benadrukt door de Ondernemingskamer van het gerechtshof te Amsterdam in het enquêteverzoek naar het beleid en de gang van zaken bij Stichting Katholieke Universiteit. ${ }^{27}$ In de beschikking van de Ondernemingskamer wordt met klem benadrukt dat bij een organisatie zoals de Radboud Universiteit 'een adequaat samengesteld orgaan niet zozeer een particuliere aangelegenheid betreft als wel een zaak van publiek belang, omdat het maatschappelijk belang is gediend bij een goede taakvervulling'. Op de vraag of het particuliere, het publieke en het maatschappelijke bij andere organisaties de boventoon moeten voeren, zal ik hier niet ingaan. Duidelijk is wel dat ongeacht de gemoeide belangensferen een behoorlijke samenstelling van het bestuur voor iedere rechts-

26. Zie Kamervraag 2015Z15666 (Kamerstukken II 2014/15).

27. Hof Amsterdam (OK) 21 juli 2020, ECLI:NL:GHAMS:2020:2033. 
persoon van belang is. Het bestuur moet immers het belang van de rechtspersoon behartigen.

Zoals eerder reeds gesignaleerd, dient de $\mathrm{RvC}$ in dit verband te waarborgen dat alle bestuurders in de praktijk aan de 'maatman-norm' voldoen en dat het bestuur als orgaan adequaat is samengesteld. Hoe valt dit echter te bewerkstelligen indien de $\mathrm{RvC}$ wordt geconfronteerd met een rechtspersoonbestuurder? Ook hier zal reglementair dan wel contractueel een regeling moeten worden getroffen waarin afspraken worden neergelegd die zien op de samenstelling van het bestuur van de rechtspersoon-bestuurder en meer in het bijzonder op de gewenste deskundigheid van de personen die de rechtspersoon-bestuurder vertegenwoordigen bij zijn taakvervulling binnen de vennootschap. Van deze personen zal de $\mathrm{RvC}$ mijns inziens mogen verwachten dat zij - gemeten naar hun persoonlijke verantwoordelijkheid - voldoen aan de 'maatmannorm' en bovenal dat zij voldoende deskundig zijn om indirect de betreffende vennootschap te kunnen besturen. Als voorbeeld noem ik specifieke sectorkennis van de branche. Het is voor de $\mathrm{RvC}$ van belang erop toe te zien dat deze deskundigheid niet ernstig fluctueert wanneer de vertegenwoordiger van de rechtspersoon-bestuurder wisselt.

Het is verder wenselijk dat de $\mathrm{RvC}$ tijdig wordt geïnformeerd over een beoogde wisseling binnen het bestuur van de rechtspersoon-bestuurder of binnen de groep van eventuele andere vertegenwoordigers van de rechtspersoon-bestuurder. Op deze wijze wordt bereikt dat de $\mathrm{RvC}$ zich tijdig een oordeel kan vormen over de impact op de feitelijke samenstelling van het bestuur als gevolg van een dergelijke wijziging. Om betrokkenheid van de $\mathrm{RvC}$ in dit geheel te kunnen waarborgen, zou reglementair dan wel contractueel een consultatierecht kunnen worden toegekend aan de $\mathrm{RvC}$ van de bestuurde rechtspersoon.

Om toezicht te kunnen houden op de taakuitoefening door de rechtspersoon-bestuurder moet tevens rekening worden gehouden met de functionerings- en beoordelingssystematiek. Zo kan worden gedacht aan het uitwerken van een regeling waarbij de natuurlijke personen die feitelijk bij de taakuitoefening van de rechtspersoon-bestuurder betrokken zijn jaarlijks door de $\mathrm{RvC}$ geëvalueerd worden. In dit kader kan ook worden gedacht aan de mogelijkheid dat de $\mathrm{RvC}$ voor deze personen een profielschets opstelt, waarop de rechtspersoonbestuurder toekomstige keuzes voor zijn vertegenwoordigers kan baseren.

\subsection{Tegenstrijdig belang}

Men dient zich tevens te bedenken dat ook een rechtspersoonbestuurder een tegenstrijdig belang kan hebben als bedoeld in artikel 2:129/239 lid 6 BW. ${ }^{28}$ Dit kan zich bijvoorbeeld voordoen indien de rechtspersoon-bestuurder tevens aandeelhouder is van de vennootschap of een overeenkomst

28. In dezelfde zin: S.M. Bartman, A.F.M. Dorresteijn \& M. Olaerts, Van het concern, Deventer: Wolters Kluwer 2020, par. 7.6.2. wordt aangegaan tussen de vennootschap en de rechtspersoonbestuurder. Bij benoeming van een rechtspersoon-bestuurder speelt echter nog een bijzondere problematiek op het gebied van tegenstrijdig belang, aangezien bij de taakuitoefening van de rechtspersoon-bestuurder verschillende personen betrokken kunnen zijn met ieder hun eigen (mogelijk tegenstrijdige) belangen.

Indachtig de Linders/Hofstee-regels is het van belang dat alle relevante tegenstrijdige belangen binnen het bestuur - en dus ook binnen de rechtspersoon-bestuurder - zorgvuldig gescheiden gehouden worden. ${ }^{29}$ De $\mathrm{RvC}$ dient dit bij zijn toezicht in acht te nemen. Daarbij is bovendien van belang dat waar de wettelijke onthoudingsregel van toepassing is, de bestuursbevoegdheid bij een 'persoonlijk tegenstrijdig belang' - een conflict van belang en plicht - van alle bestuurders verlegd wordt naar de $\mathrm{RvC}$ (art. 2:129/239 lid 6 BW). ${ }^{30}$ Om deze escalatie soepel te laten verlopen, verdient het aanbeveling om vooraf reglementair te bepalen hoe het bestuur en de $\mathrm{RvC}$ met dergelijke situaties omgaan, en daarbij tevens aandacht te hebben voor de bijzondere positie van de rechtspersoon-bestuurder, die immers diverse persoonlijke belangen in zich verenigt.

\subsection{Registratieplicht organisatie rechtspersoon- bestuurder?}

Eerder heb ik gerefereerd aan de discussie ten aanzien van de (on)wenselijkheid van het introduceren van de verplichting voor rechtspersoon-bestuurders tot aanwijzing van een vaste vertegenwoordiger-natuurlijke persoon. $\mathrm{Nu}$ de door mij gesignaleerde problemen zien op de interne verhoudingen binnen de door de rechtspersoon-bestuurder bestuurde rechtspersoon kan de oplossing om tot meer transparantie te komen wellicht ook intern gevonden worden zonder dat een vaste vertegenwoordiger (extern) dient te worden aangewezen. Rechtspersonen waarbij een rechtspersoon als bestuurder wordt benoemd, zouden kunnen worden verplicht om, in een door de rechtspersoon aan te houden register, informatie neer te leggen waaruit ten minste het volgende blijkt:

1. hoe het bestuur van de rechtspersoon-bestuurder is samengesteld;

2. of aan het bestuur van de rechtspersoon-bestuurder instructies of beperkingen zijn opgelegd die zien op de uitoefening van de bestuursfunctie door de rechtspersoonbestuurder;

3. of andere personen dan de bestuurders de rechtspersoonbestuurder kunnen vertegenwoordigen, en zo ja, de personalia van deze personen en de aard en omvang van de vertegenwoordigingsbevoegdheid;

29. Hof Amsterdam (OK) 26 mei 1983, ECLI:NL:GHAMS:1983:AC8007, NJ 1984/481 m.nt. J.M.M. Maeijer (Linders/Hofstee).

30. Zie over het onderscheid tussen conflict van belang en plicht en het conflict van plichten A.F.J.A. Leijten, Bestuur en tegenstrijdig belang, Ondernemingsrecht 2019/80. Zie verder over Linders/Hofstee en de wettelijke tegenstrijdigbelangregels J.M. de Jongh, Twee eeuwen tegenstrijdig belang, Den Haag: Boom juridisch 2019, hoofdstuk 12. 
4. welke natuurlijke persoon of personen namens de rechtspersoon-bestuurder als eerste aanspreekpunt voor de $\mathrm{RvC}$ dienen te worden beschouwd.

Vennootschappen kennen al de verplichting om een register aan te houden waarin de namen en adressen van alle houders van aandelen op naam zijn opgenomen. ${ }^{31}$ Ook coöperaties houden in de praktijk ledenregisters aan. Het doel van een dergelijk register is het mogelijk maken van adequate communicatie tussen de rechtspersoon en zijn aandeelhouders/leden. Het registreren van informatie ten aanzien van de rechtspersoon-bestuurder dient feitelijk hetzelfde doel. Slechts een relatief eenvoudige wetswijziging is hiertoe nodig, en ik zie weinig materiële bezwaren tegen het invoeren van een dergelijke registratieplicht.

\section{Transparantie rechtspersoon-bestuurder; vrijwilligheid of verplichting?}

Het uitgangspunt van de eerder aangedragen suggesties om te komen tot meer transparantie als het gaat om het functioneren van de rechtspersoon-bestuurder en de onderlinge communicatie tussen bestuur en $\mathrm{RvC}$ is, bij gebrek aan wettelijke regeling, gebaseerd op vrijwilligheid. Wat nu indien een rechtspersoon-bestuurder zich onwelwillend opstelt en niet voornemens is om de $\mathrm{RvC}$ van meer informatie te voorzien dan blijkt uit de registratie van de rechtspersoon-bestuurder in het handelsregister van de Kamer van Koophandel?

Naast het feit dat ik zou menen dat de redelijkheid en billijkheid van artikel 2:8 BW met zich meebrengen dat de rechtspersoon-bestuurder gehouden is tot het verlenen van medewerking aan het tot stand brengen van een hierboven voorgestelde regeling, ben ik van mening dat het bestuur, gevormd door de rechtspersoon-bestuurder, ook verplicht is tot het verschaffen van alle in dit verband door de $\mathrm{RvC}$ benodigde informatie. Op grond van artikel 2:141/251 BW verschaft het bestuur de RvC immers tijdig de 'voor de uitoefening van diens taak noodzakelijke gegevens'. Zoals eerder al opgemerkt, is het waarborgen van duidelijke communicatielijnen, in het belang van de onderlinge dialoog tussen bestuur en $\mathrm{RvC}$, essentieel voor de taakuitoefening door de $\mathrm{RvC}$. Zo dient het volstrekt duidelijk te zijn welke natuurlijke persoon of personen uiteindelijk belast zijn met het namens de rechtspersoon-bestuurder vervullen van de bestuursfunctie. Zodoende kan de $\mathrm{RvC}$ communiceren met de rechtspersoonbestuurder en zich een oordeel vormen over de deskundigheid binnen het bestuur, en kan hij op de hoogte zijn van mogelijke (interne) beperkingen voor wat betreft de uitoefening van de bestuurstak. Indien het bestuur (gevormd door de rechtspersoon-bestuurder) niet of niet tijdig tegemoetkomt aan een dergelijk verzoek tot het verschaffen van informatie, kan dit handelen worden bestempeld als onzorgvuldig. ${ }^{32} \mathrm{De} \mathrm{RvC}$ heeft als uiterste remedie de mogelijkheid om de bestuurder te

31. Ingevolge art. 2:85/194 BW.

32. HR 10 januari 1990, ECLI:NL:HR:1990:AC1234, NJ 1990/466 (Ogem). schorsen op grond van artikel 2:147/257 BW, voor zover de statuten deze mogelijkheid niet beperkt of uitgesloten hebben. Mocht de bevoegdheid tot schorsing statutair zijn uitgesloten, dan zou de $\mathrm{RvC}$ zich tot de rechter kunnen wenden om het verschaffen van gevraagde informatie rechtens af te dwingen.

Voor de $\mathrm{RvC}$ is van belang dat het initiatief tot het verzoeken om informatie bij de RvC zelf ligt. Gesteld zou kunnen worden dat de bestuurder-rechtspersoon in deze context ook een brengplicht heeft. In beginsel mag de $\mathrm{RvC}$ uitgaan van de juistheid van de door het bestuur verschafte informatie. Onder omstandigheden zal de $\mathrm{RvC}$ echter gehouden zijn kritische vragen te stellen en om aanvullende informatie moeten vragen indien daartoe aanleiding is. Hierbij kan bijvoorbeeld worden gedacht aan de situatie dat een niet-statutair bestuurder wordt aangemerkt als 'vaste vertegenwoordiger' namens de rechtspersoon-bestuurder: de RvC zal in dat geval moeten vragen om aanvullende documentatie waaruit de bevoegdheid van deze persoon valt af te leiden.

Met de introductie van een registratieplicht zoals voorgesteld in paragraaf 5.4, op basis waarvan de rechtspersoon-bestuurder informatie moet registreren, kan een dergelijke discussie worden voorkomen.

\section{Afsluiting}

De rechtspersoon-bestuurder is niet meer weg te denken uit de rechtspraktijk. De inrichtingsvrijheid binnen de vennootschap voorziet in de behoefte van de praktijk om op een efficiënte wijze bestuursfuncties (veelal in groepsverband) door rechtspersonen te laten bekleden. Er zijn echter gevallen waarin naast een statutair bestuur een toezichthoudend orgaan in de vorm van een $\mathrm{RvC}$ is ingesteld (of in geval van de one-tier board: de niet-uitvoerende bestuurders). In dergelijke gevallen komt de vraag op hoe adequaat toezicht gehouden kan worden op het bestuur.

In mijn bijdrage heb ik enkele punten van aandacht bij de uitoefening van de bestuurstaak door een rechtspersoonbestuurder geadresseerd die van belang zijn voor de RvC. Tevens ben ik ingegaan op de uitoefening van de toezichthoudende rol door de $\mathrm{RvC}$ indien deze wordt geconfronteerd met een rechtspersoon die is benoemd tot bestuurder van een rechtspersoon.

Een adequaat toezicht op de rechtspersoon-bestuurder is mogelijk. Bij gebrek aan wetgeving is het echter voor de praktijk van belang nadere afspraken te maken en regelingen te treffen ter waarborging van de checks and balances in de verhouding tussen bestuur en $\mathrm{RvC}$. Een one size fits all-benadering volstaat hier niet. In mijn bijdrage heb ik hiertoe enkele aanbevelingen gedaan.

Om tot (meer) transparantie en inzicht ten aanzien van de rechtspersoon-bestuurder te komen doet een $\mathrm{RvC}$ er goed aan de rechtspersoon-bestuurder te wijzen op zijn informatie- 


\section{Maandblad}

plicht. Een registratieplicht als nadere invulling van deze informatieplicht, zoals voorgesteld in paragraaf 5.4, zorgt voor duidelijkheid en meer transparantie binnen de rechtspersoon en draagt daarmee bij aan het beter kunnen functioneren van het door de $\mathrm{RvC}$ uit te oefenen toezicht.

Bij gebrek aan een wettelijke regeling doen de rechtspersoonbestuurder en de $\mathrm{RvC}$ er goed aan om reglementair dan wel contractueel vast te leggen hoe namens de rechtspersoonbestuurder de bestuurstaak zal worden uitgeoefend en het toezicht op de uitoefening van de bestuurstaak zal worden vormgegeven. Van belang is echter dat bij het ontbreken van een wettelijke verplichting om bijvoorbeeld een vaste vertegenwoordiger aan te wijzen, de $\mathrm{RvC}$ op basis van huidig recht voldoende instrumenten heeft om een rechtspersoonbestuurder te dwingen tot het verschaffen van informatie.

Naar mijn mening ziet deze informatieplicht niet alleen op informatie die de door de rechtspersoon-bestuurder bestuurde rechtspersoon aangaat, maar ook op informatie ten aanzien van de uitoefening van de bestuurstaak door de rechtspersoonbestuurder. Artikel 2:141/251 BW bepaalt immers dat het bestuur gehouden is de informatie te geven die noodzakelijk is voor de uitoefening van de taak van de $\mathrm{RvC}$. Als voor een $\mathrm{RvC}$ niet duidelijk is wie namens de rechtspersoon-bestuurder feitelijk bestuurt, kan er onmogelijk toezicht gehouden worden. Indien de rechtspersoon-bestuurder deze informatie niet uit eigen beweging deelt met de $\mathrm{RvC}$, ligt er voor de $\mathrm{RvC}$ een actieve rol om deze informatie op te vragen. Bij het uitblijven van gevraagde informatie kan de $\mathrm{RvC}$ zich genoodzaakt zien de rechtspersoon-bestuurder te schorsen (indien statutair mogelijk) of zich te wenden tot de rechter. 